\title{
Characterization of filamentous bacteria, belonging to candidate phylum KSB3, that are associated with bulking in methanogenic granular sludges
}

\author{
Takeshi Yamada ${ }^{1,2}$, Toshihiro Yamauchi ${ }^{3}$, Koji Shiraishi ${ }^{3}$, Philip Hugenholtz ${ }^{4}$, \\ Akiyoshi Ohashi $^{2}$, Hideki Harada ${ }^{2,5}$, Yoichi Kamagata ${ }^{1,2}$, Kazunori Nakamura ${ }^{1}$ \\ and Yuji Sekiguchi ${ }^{1,2}$ \\ ${ }^{1}$ Institute for Biological Resources and Functions, National Institute of Advanced Industrial Science and \\ Technology (AIST), Tsukuba, Ibaraki, Japan; ${ }^{2}$ Department of Environmental Systems Engineering, Nagaoka \\ University of Technology, Nagaoka, Niigata, Japan; ${ }^{3}$ Research and Development Division, Fujikasui \\ Engineering Co., Ltd, Shinagawa, Tokyo, Japan; ${ }^{4}$ Microbial Ecology Program, DOE Joint Genome Institute, \\ Walnut Creek, CA, USA and ${ }^{5}$ Department of Civil Engineering, Tohoku University, Sendai, Miyagi, Japan
}

\begin{abstract}
A fatal bulking phenomenon was found to occur occasionally in the methanogenic granular sludge of a mesophilic $\left(35-40^{\circ} \mathrm{C}\right)$, full-scale upflow anaerobic sludge blanket (UASB) reactor treating organic wastewater discharged from a sugar manufacturing factory. A vast number of filamentous cells were observed in the bulking sludge that were morphologically distinct from the previously recognized anaerobic bulking agent Anaerolinea thermophila. 16S rRNA gene-based analyses of the microbial populations in the bulking sludge revealed that the dominant filamentous organisms were members of proposed candidate bacterial phylum, KSB3. Fluorescence in situ hybridization (FISH) analysis of the healthy sludge granules showed that the KSB3 filaments were the dominant granule surface population suggesting that they are fundamental constituents of the sludge granules and that they occasionally overgrow in the reactor, possibly triggering the filamentous bulking. We surveyed 10 additional mesophilic and thermophilic anaerobic sludges for the presence and diversity of KSB3 populations. Bacteria closely related to the characterized KSB3 filaments were present in two types of mesophilically grown UASB sludge granules treating actual wastewater discharged from sugar-processing industries.
\end{abstract}

The ISME Journal (2007) 1, 246-255; doi:10.1038/ismej.2007.28; published online 31 May 2007

Subject Category: microbial ecology and functional diversity of natural habitats

Keywords: anaerobic filamentous bulking; upflow anaerobic sludge blanket (UASB); KSB3; filamentous microbes; wastewater treatment

\section{Introduction}

The upflow anaerobic sludge blanket (UASB) process is a mature technology for treating mediumand high-strength organic wastewaters (Lettinga, 1995; Sekiguchi and Kamagata, 2004) with more than 850 commercial UASB processes in use around the world (Kleerebenzem and Macarie, 2003). The range of wastewaters that can be treated using the technology is now expanding to include lowstrength wastewater (Uemura and Harada, 2000),

Correspondence: Dr Y Sekiguchi, Bio-Measurement Research Group, Institute for Biological Resources and Functions, National Institute of Advanced Industrial Science and Technology (AIST), Central 6, 1-1-1 Higashi, Tsukuba, Ibaraki 305-8566, Japan.

E-mail: y.sekiguchi@aist.go.jp

Received 27 October 2006; revised and accepted 14 March 2007; published online 31 May 2007 wastewater under hyperthermophilic (Lepistö and Rintala, 1999; Vallero et al., 2004) and psychrophilic conditions (Rebac et al., 1999; Lettinga et al., 2001), and more complex wastewaters containing anthropogenic compounds and/or compounds recalcitrant to biodegradation (Donlon et al., 1997; van der Zee et al., 2001). With an increasing demand on the application of UASB technology, serious performance problems are also on the rise (Sekiguchi and Kamagata, 2004). The sudden washout of granular sludge from the reactor vessel is one such problem associated with treatment of various types of high-strength organic wastewater (for example carbohydrate-containing wastewater) (Yoda et al., 1989; Wu et al., 1993; Alphenaar, 1994; Angenent and Sung, 2001; Sekiguchi et al., 2001). Since the high-rate treatment of wastewater by UASB depends on retention of high concentrations of biomass in the 
reactor vessel (as sludge granules), the floatation and subsequent washout of granular sludge severely affects treatment performance often leading to complete loss of performance.

One cause of floatation is gas bubble entrapment within sludge granules. Sludge granules have been observed by scanning electron microscopy (SEM) and fluorescence in situ hybridization (FISH) (Harmsen et al., 1996; Sekiguchi et al., 1999) to have cavities in their cores, and these cavities in which gas bubbles become entrapped provide buoyancy for floatation to occur (Kosaric et al., 1990; Yoda and Nishimura, 1997). Addition of Fe to the process was reported to be an effective means of avoiding gas entrapment, because $\mathrm{FeS}$ particles were suggested to form and subsequently accumulate in the empty space of the sludge granules (Yoda and Nishimura, 1997). Formation of fluffy granules is another cause of sludge floatation found in various UASB reactors. The majority of the fluffy UASB sludge granules reported so far were known to be caused by the overgrowth of certain types of filamentous microorganisms (anaerobic filamentous sludge bulking) (Yoda et al., 1989; Wu et al., 1993; Alphenaar, 1994; Angenent and Sung, 2001; Sekiguchi et al., 2001). Similar sludge floatation was also reported for anaerobic contact processes (Endo and Tohya, 1988). Although various morphologically distinct types of filamentous cells have been observed in fluffy anaerobic sludges, little is known about the physiology or phylogeny of these organisms. Recently, the filamentous anaerobe Anaerolinea thermophila has been identified as a causative agent of fluffy sludge in a thermophilic UASB process. This is the first well-characterized bulking agent of anaerobic sludge (Sekiguchi et al., 2001, 2003).

We found fluffy sludge granules causing severe sludge bulking in a full-scale mesophilic UASB process that had been treating a high-strength organic wastewater discharged from a sugar-manufacturing factory. Unidentified filamentous organisms morphologically distinct from $A$. thermophila were found to be the dominant morphotype in the bulking sludge. In this paper, we first attempted to identify these filaments using $16 \mathrm{~S}$ rRNA-based analyses, then determined their spatial organization in bulking and non-bulking sludge granules using FISH with confocal laser scanning microscopy (CLSM), and SEM. Finally, to determine the extent and phylogenetic diversity of KSB3 filaments in anaerobic sludges, we performed 16S rRNA genebased analyses for ten different types of UASB sludges and digester sludges.

\section{Materials and methods}

Operation of anaerobic processes

Seven different types of UASB sludge granules (AMG, BMG, CMG, ATG, STG, PMG and PTG) and three types of digester sludges (NMD, JTD and OTD) were used in this study (Table 1). AMG, BMG, CMG, ATG and STG reactors were fed with wastewater as described previously (Yamada et al., 2005). PMG and PTG reactors treated wastewater discharged from the same palm oil-manufacturing plant. NMD and OTD reactors have digested sewage sludges, and JTD has decomposed domestic organic wastes. All reactors exhibited good performance for chemical oxygen demand (COD) removal as well as methane formation (with $45-85 \%$ methane conversion rates) at the sampling date.

Bulking sludges and sludge granules (before bulking) were collected from a mesophilic $\left(35-40^{\circ} \mathrm{C}\right)$, fullscale UASB process (reactor volume: approximately $400 \mathrm{~m}^{3}$ ) used to treat an actual organic wastewater discharged from a sugar-manufacturing factory (CMG reactor) (Yamada et al., 2005). Before the bulking occurred, the UASB process had exhibited good treatment performance for COD removal (with 90 to $95 \%$ removal efficiencies) as well as good methane formation (with more than $80 \%$ methane conversion rates). Sludge granules (1-2 $\mathrm{mm}$ in diameter) that settled well had been successfully formed in the reactor.

Construction of $16 S$ rRNA gene clone library for bulking sludge and other anaerobic sludges

DNA extraction from bulking sludge samples was performed based on the method of Miller et al., (1999) with slight modifications as described previously (Yamada et al., 2005). PCR amplification of $16 \mathrm{~S}$ rRNA genes and subsequent cloning were performed according to a previous report (Sekiguchi et al., 1998). 16S rRNA gene amplification was performed using a Bacteria-specific primer set: that is the domain Bacteria-specific primer 27f (5'- AGAG TTTGATCCTGGCTCAG-3' ${ }^{\prime}$, Escherichia coli position 8-27) and the universal primer 1492r (5'-GGTTAC CTTGTTACGACTT-3', E. coli position 1491-1509) (Weisburg et al., 1991). The amplified PCR product was purified with a Microspin column (GE Healthcare, Uppsala, Sweden) and cloned using a TA cloning kit (Novagen, San Diego, USA). Thirty clonal rRNA genes were randomly picked from the clone library for further analysis.

To construct 16S rRNA gene clone libraries of the members of the phylum KSB3, we extracted DNA from the anaerobic sludge samples, and then amplified 16S rRNA genes belonging to the KSB3 phylum using 27f (Weisburg et al., 1991) and a KSB3-specific primer 3KSB1238r (5'-CCGCTGTCC TCCCCATT-3', E. coli position 1238-1245) designed in this study (Table 3). PCR amplification and subsequent cloning were carried out as mentioned above. Ten clonal rRNA genes were randomly picked from the clone libraries for further analysis.

Sequencing and phylogenetic analyses

Clone sequences were determined with a $\mathrm{CEQ}^{\mathrm{TM}}$ DTC kit-Quick start kit (Beckman Coulter, Fullerton, 
Table 1 Operation conditions of UASB reactors and digested sludge reactors used in this study

\begin{tabular}{|c|c|c|c|c|c|c|c|}
\hline \multirow{2}{*}{ Reactor } & \multirow[t]{2}{*}{ Type } & \multicolumn{6}{|c|}{ Reactor conditions } \\
\hline & & $\underset{\left(m^{3}\right)}{\text { Volume }}$ & $\begin{array}{l}\text { Temperature } \\
\left({ }^{\circ} \mathrm{C}\right)\end{array}$ & Type of wastewater & $\begin{array}{l}\text { COD loading ( } \mathrm{kg} \\
\left.\text { COD } / \mathrm{m}^{3} / \text { day }\right)\end{array}$ & $\begin{array}{l}\text { Influent COD } \\
\text { concentration } \\
\quad(\mathrm{mg} / \mathrm{l})\end{array}$ & $\begin{array}{l}\text { COD removal } \\
\text { efficiency (\%) }\end{array}$ \\
\hline AMG & UASB & 0.013 & 37 & Artificial wastewater ${ }^{\mathrm{a}}$ & 6 & 2000 & $>95$ \\
\hline BMG & UASB & $\sim 900$ & $30-36$ & $\begin{array}{l}\text { Actual wastewater (from a beer } \\
\text { factory) }\end{array}$ & 0.34 & $200-300$ & $>90$ \\
\hline CMG & UASB & $\sim 400$ & $35-40$ & $\begin{array}{l}\text { Actual wastewater (from a sugar } \\
\text { manufacturing factory) }\end{array}$ & 9 & 2000 & $90-95$ \\
\hline PMG & UASB & 0.013 & 37 & $\begin{array}{l}\text { Actural wastewater (from a palm-oil } \\
\text { manufacturing factory) }\end{array}$ & 10 & 2000 & 85 \\
\hline ATG & UASB & 0.013 & 55 & Artificial wastewater ${ }^{a}$ & 10 & 3000 & $>95$ \\
\hline STG & UASB & 0.013 & 55 & $\begin{array}{l}\text { Actual wastewater (from a shochu } \\
\text { manufacturing factory) }\end{array}$ & 100 & 10000 & $>95$ \\
\hline PTG & UASB & 0.013 & 55 & $\begin{array}{l}\text { Actural waterwater (from a palm-oil } \\
\text { manufacturing factory) }\end{array}$ & 12 & 2000 & 74 \\
\hline NMD & $\begin{array}{l}\text { digester } \\
\text { sludge }\end{array}$ & $\sim 3000$ & 37 & Settled sewage sludges & 6.5 & 58000 & 60 \\
\hline ODT & $\begin{array}{l}\text { digester } \\
\text { sludge }\end{array}$ & 2000 & 55 & Settled sewage sludges & 9.8 & 59000 & 60 \\
\hline JTD & $\begin{array}{l}\text { digester } \\
\text { sludge }\end{array}$ & $\sim 900$ & 55 & Domesitic garbage & 7.5 & 155000 & 60 \\
\hline
\end{tabular}

${ }^{\mathrm{a} A r t i f i c i a l ~ w a s t e w a t e r: ~ s u c r o s e, ~ a c e t a t e, ~ p r o p i o n a t e, ~ p e p t o n e ~([C O D] ~ r a t i o ~ 4.5: 2.25: 2.25: 1) . ~}$

USA) and an automated sequence analyzer (model CEQ-2000; Beckman Coulter). Sequence data were aligned in an ARB data set using the ARB program package (Ludwig et al., 2004) and the aligned data were manually corrected by using the editing tool in the package (Ludwig et al., 2004). The phylogenetic placements of all 16S rRNA gene sequences were determined using the neighbor-joining method (Saitou and Nei, 1987), implemented in the ARB program (substitution correction model: Olsen correction). To estimate the confidence of tree topologies, bootstrap resampling analysis (Felsenstein, 1985) for 1000 replicates was performed with the PAUP* 4.0 program package (Swofford, 2002). Clonal sequences that have $100 \%$ sequence identity with each other were grouped into one phylotype. Chimeric sequences were checked by partial treeing analysis (Hugenholtz and Huber, 2003). The phylotypes found in the clone libraries were designated as follows: YM-1 from the clone library for the bulking sludges, BUM1 from the clone library for BMG sludge, and CUM1 to CUM4 from the clone library for CMG sludge. The phylogenetic position of clone YM-1 was confirmed using maximum parsimony in PAUP* 4.0 package (Swofford, 2002), maximum likelihood using the TREEFINDER program package (Jobb, 2005), and Bayesian analysis using MrBayes v3.1 (Ronquist and Huelsenbeck, 2003), under a variety of outgroup conditions as described previously (Zhang et al., 2003). Bootstrap resampling analysis (Felsenstein, 1985) for 1000 replicates was also performed for neighbor-joining, maximum likelihood, and maximum parsimony analyses to estimate the confidence of inferred tree topologies. In addition, posterior probabilities of branching points were estimated by the Bayesian inference as mentioned previously (Zhang et al., 2003).

\section{FISH}

Fixation of sludge samples and whole-cell in situ hybridization of dispersed bulking sludges were performed as described previously (Sekiguchi et al., 1999; Yamada et al., 2005). The 16S rRNAtargeted oligonucleotide probes used in this study are detailed in Table 3. A mixture of EUB338, EUB338-II and EUB338-III (Amann et al., 1990; Daims et al., 1999) was used as the probe EUB338* specific for the domain Bacteria. Members of the phylum Chloroflexi, that includes Anaerolinea thermophila, were detected using GNSB941 (Gich et al., 2001; Björnsson et al., 2002). To ensure fidelity of this probe, we added an unlabeled competitor GNSB941* (Table 3), which is exactly complementary to a number of non-target organisms with only one base mismatch to GNSB941 (the 
GNSB941 and GNSB941* probe mixture was equimolar).

For the detection of the targeted KSB3 filamentous bacteria in the bulking sludge and healthy sludge granules, we designed three probes specific for bulking sludge clone YM-1 (3KSB129, 3KSB652, 3KSB1128) and one probe, 3KSB1238, targeting the whole KSB3 group (Table 3). All probes were labeled with either Cy-3 or Cy-5 for in situ hybridization. Probe specificity was tested using the following reference strains as negative control: Chloroflexus aurantiacus (DSM 635), Anaerolinea thermophila (DSM 14523), Clostridium acetobutyricum (DSM 792) and Desulfotomaculum thermobenzoicum (DSM 6193). The specificity of each probe was also tested with the bulking sludge and the ten healthy sludges used in this study (Table 1). Briefly, stringent conditions were determined for each probe with the bulking sludge first, in which the predominant filaments were specifically detected, and then the FISH using the probes under the same conditions were applied to the reference strains and the healthy sludges to confirm that the conditions do not allow the detection of the reference strains and other morphotypes of cells in the sludges. The hybridization stringency was adjusted by adding formamide to hybridization buffer (Table 3). A microscope equipped for epifluorescence was used for observation (Olympus BX50F).

Thin-sections of well-settling granules in normally functioning sludge were prepared as described previously (Yamada et al., 2005). The sections were immobilized on glass slides coated with Vectabond (Vector Laboratories, Burlingame, USA) for FISH experiments. FISH analyses for the thin sections were performed as described previously (Sekiguchi et al., 1999). The sections were observed with a confocal laser scanning microscope (CLSM) (LSM 5 PASCAL, ZEISS). Sections from at least 20 granule pellets were examined under a CLSM to observe the general microbial structure of the sludge.

\section{SEM and analytical methods}

SEM observations were performed with a HitachiS4500 SEM as described previously (Uemura and Harada, 1993). Short-chain fatty acids and other organic acids were determined using a high-pressure liquid chromatograph (HPLC) with an SCR-102$\mathrm{H}$ column (Shimadzu) and a conductivity detector (Shimadzu CDD-6A) (Imachi et al., 2002). Carbohydrates were determined by an HPLC using an SCR101-H column (Shimadzu) with a refractive index detector (Shimadzu RID-10A) (Sekiguchi et al., 2001). Inorganic nitrogenous compounds were determined with an HPLC with an IC-A1 column (Shimadzu) and a conductivity detector (Shimadzu CDD-6A) (Yamaguchi et al., 2001). Organic nitrogen compounds were measured with the Kjeldahl method (Clesceri et al., 1998), and the total amont of sulfurous compounds was determined with the methylene blue method (Clesceri et al., 1998). Proteins were determined by the Lowry method (Lowry et al., 1951).

\section{Nucleotide sequence accession number}

All 16S rRNA gene sequences of the clones analyzed in this study were deposited in the DDBJ/EMBL/ GenBank databases under accession numbers AB218870-AB218875.

\section{Results}

UASB sludge bulking phenomenon

Sludge bulking was occasionally (and suddenly) observed in a mesophilic, full-scale UASB process (CMG reactor in Table 1) treating wastewater from a sugar-manufacturing factory (the factory processes starch for the production of various types of sugars, such as maltose and isomerized sugar). In this case, wastewater was discharged from various production lines within the manufacturing plant, and was composed of complex organic compounds mainly containing volatile fatty acids, carbohydrates, and proteins (Table 2). Before bulking occurred, wellsettleable sludge granules with a mean diameter of 1-2 mm (Figure 1d) were observed as the main part of the retained sludge within the reactor, and the reactor had successfully treated the wastewater at a volumetric loading rate of $9-10 \mathrm{~kg} \mathrm{COD} / \mathrm{m}^{3} /$ day. However, once bulking occurred, a large part of the retained sludge overflowed with the effluent stream owing to the floatation of the sludge bed. Within the floated sludge, white cotton-like fluffy sludge was observed, which often formed fluffy aggregates entrapping healthy sludge granules (Figure 1a).

Table 2 An example of wastewater compositions for the reactor CMG, discharged from various lines of sugar-producing processes (chemical compositions of the wastewater under normal treatment conditions without bulking)

\begin{tabular}{lc}
\hline $\mathrm{PH}$ & 6.2 \\
Temperature $\left({ }^{\circ} \mathrm{C}\right)$ & $35-40$ \\
& \\
CODcr (mg COD/l) & 1380 \\
Lactate (mg COD/l) & 13.0 \\
Formate (mg COD/l) & 4.0 \\
Acetate (mg COD/l) & 386.0 \\
Propionate (mg COD/l) & 375.0 \\
iso-Butyrate (mg COD/l) & 245.0 \\
Butyrate (mg COD/l) & 19.0 \\
& \\
Carbohydrates (mg COD/l) & 18.0 \\
Protein (mg COD/l) & 123.0 \\
& \\
Total sulfur (mg S/l) & 13.0 \\
& \\
Total nitrogen (mg N/l) & 25.0 \\
$\mathrm{NH}_{4}$ (mg N/l) & 17.0 \\
$\mathrm{NO}_{2}$ (mg N/l) & $<0.02$ \\
$\mathrm{NO}_{3}$ (mg N/l) & $<0.02$ \\
$\mathrm{Organic} \mathrm{nitrogen} \mathrm{(mg} \mathrm{N/l)}$ & 8.0
\end{tabular}



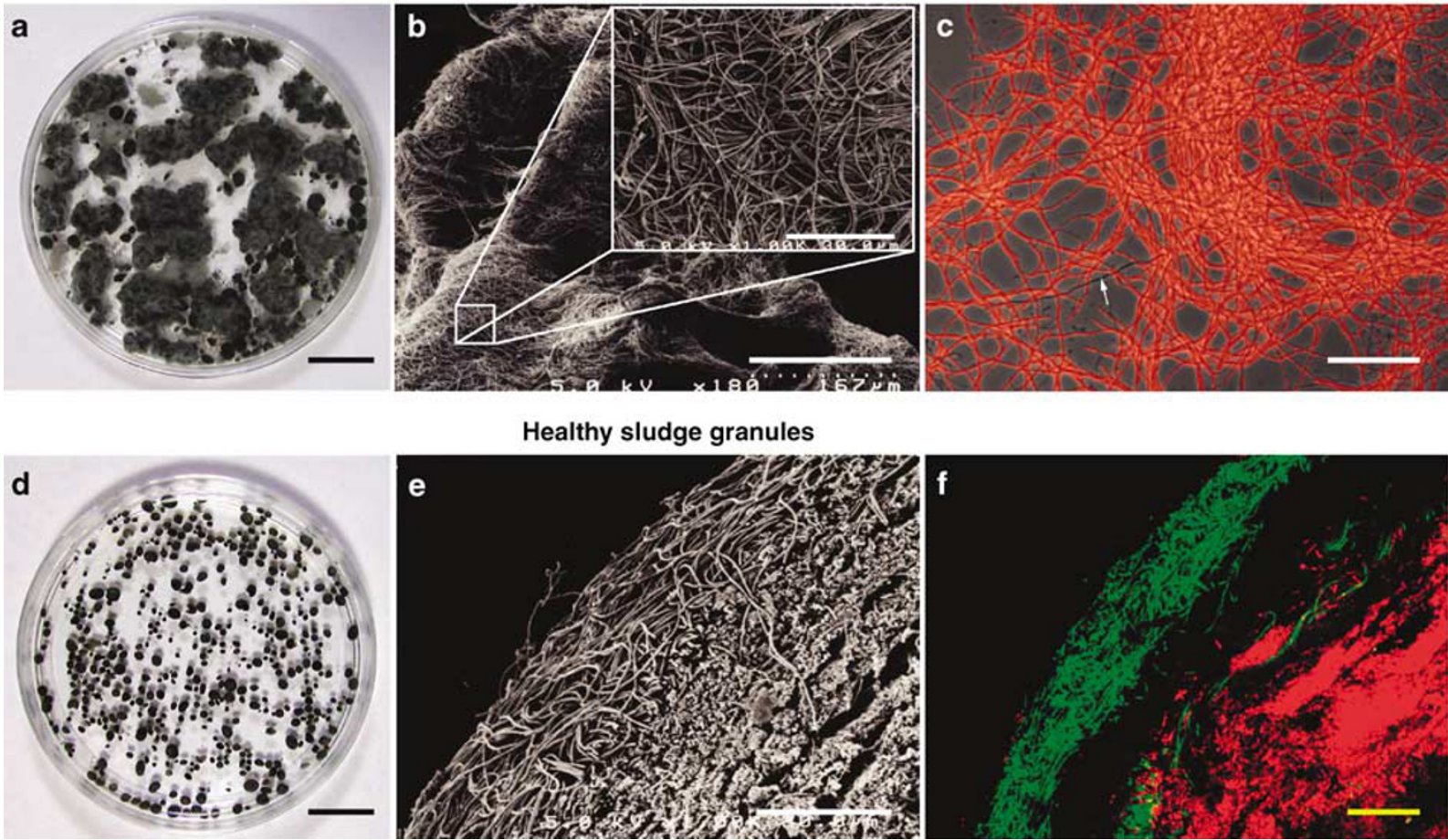

Figure 1 Observations of bulking sludge found in the CMG reactor (a-c). (a) Photograph of the bulking sludge (bar, 1 mm). Scanning electron micrographs of (b) fluffy, cotton-like material in the bulking sludge (bar, $167 \mu \mathrm{m}$ ) and the inset in (b) shows a magnified view of the surface of the fluffy material (bar, $30 \mu \mathrm{m}$ ). In situ hybridization of filamentous cells in the fluffy part of the bulking sludge with the Cy3-labeled 3KSB1238 probe (c), in which the FISH micrograph was imposed on the phase-contrast micrograph of the same field of the FISH image. The arrow in (c) indicates filamentous cells that do not react with the probe. Observations of series of well-settleable healthy granules (before bulking) from the same reactor $(\mathbf{d}-\mathbf{f})$. (d) A photograph of the granules that settled well (bar, $1 \mathrm{~mm}$ ); (e) a scanning electron micrograph of a section of a granule (bar, $30 \mu \mathrm{m}$ ); (f) a section hybridized with Cy3-labeled 3KSB1238 probe, specific for the phylum KSB3 (green) and Cy5-labeled probe ARC915, specific for the domain Archaea (red) (bar, $20 \mu \mathrm{m}$ ), viewed by confocal laser scanning microscopy.

The white cotton-like material also entrapped gas bubbles produced within the reactor contributing to the buoyancy of the sludge in the reactor vessel. Microscopically, the cotton-like material comprised predominantly filamentous cells that are much thicker than the known anaerobic bulking agent $A$. thermophila (Sekiguchi et al., 2001, 2003) (Figure 1b and c). The washout of the retained sludge led to process failure, and the same bulking phenomenon was observed on multiple occasions in the bioreactor following reseeding.

\section{Phylogenetic affiliation of the predominant}

filamentous cells in the bulking sludge

To reveal the phylogenetic identity of the filamentous microbes, we first applied FISH using various 16S rRNA-targeted oligonucleotide probes to the dispersed bulking sludge samples. FISH analyses using the domain specific-probes EUB338* and ARC915 for Bacteria and Archaea indicated that the abundant thick-filamentous cells in the bulking sludges are bacterial. Since the only characterized anaerobic bulking agent, $A$. thermophila, belongs to the bacterial phylum Chloroflexi (Sekiguchi et al., 2001), we probed the bulking sludge with the Chloroflexi-specific probe GNSB941, which indicated that the observed filaments are not members of this phylum. We then constructed a clone library for bacterial 16S rRNA genes from the cotton-like aggregates. Among thirty clones analyzed, four phylotypes were found, none of which could be identified as chimeric artifacts. The nearly full-length sequence of clone YM-1, representing the most abundant phylotype (27 of 30 clones), was determined (1475 nt). Comparative analysis of this clone sequence with reference sequences obtained from the public databases indicated that YM-1, together with seven other partial to near full-length (659 to $1512 \mathrm{nt}$ ) environmental clone sequences, represent a robustly monophyletic and unaffiliated lineage in the bacterial domain (Figure 2). This phylogenetic novelty was recognized previously by Tanner et al. (2000) and Ley et al. (2006), who proposed naming the group candidate phylum KSB3 and GN6, respectively. The other three phylotypes present in the bulking sludge library belong to the phyla Spirochetes (2/30 clones) and Fusobacteria (1/30 clones).

To detect the cells represented as the clone YM-1 within the sludge sample, 16S rRNA-targeted FISH experiments were performed using the oligonucleo- 


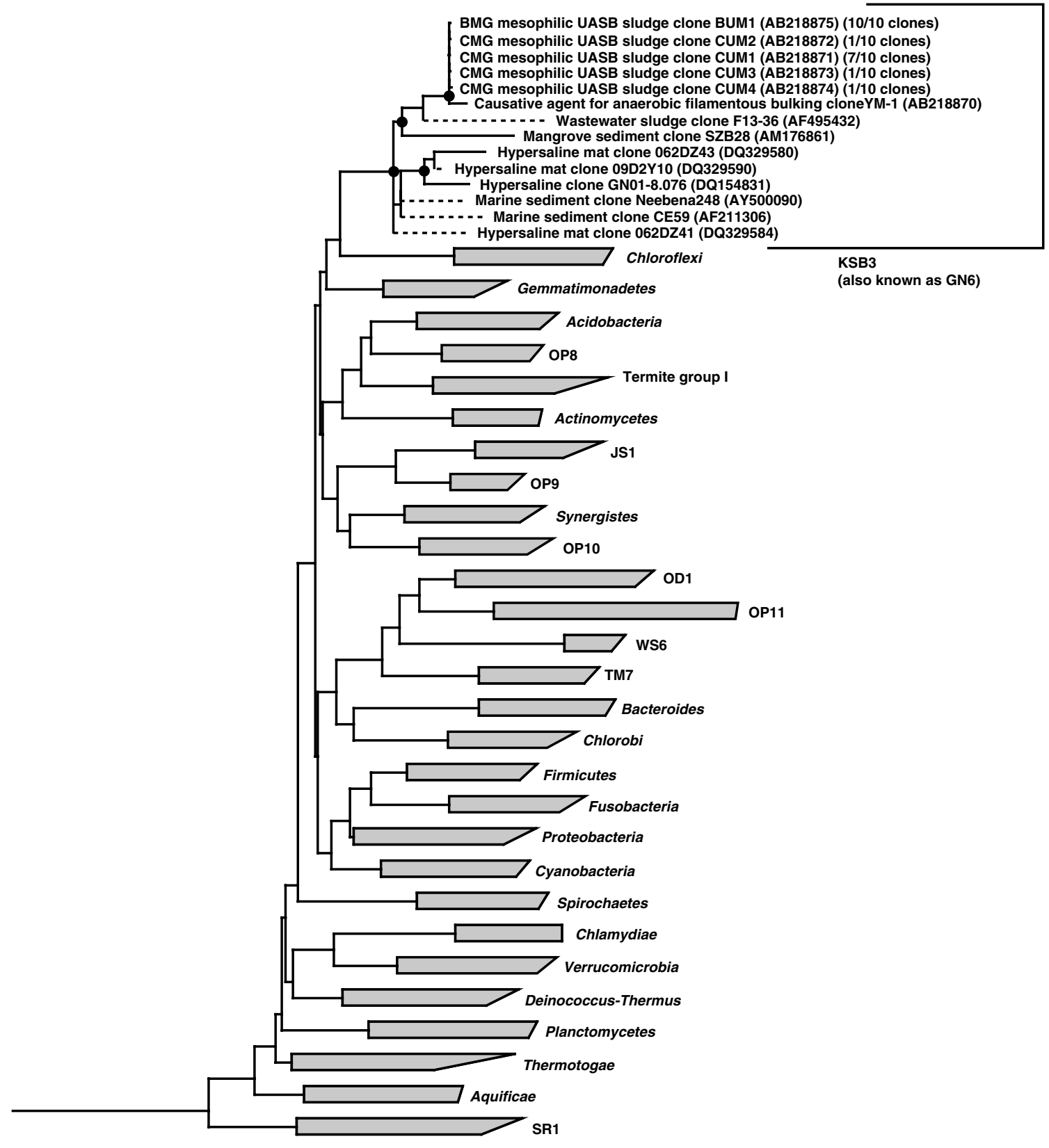

0.10

Figure 2 Evolutionary dendrogram showing the phylogenetic placement of the clone YM-1, which was most abundantly retrieved from the fluffy part of the bulking sludge, and the clones obtained from two types of granular sludges, based on 16S rRNA gene sequences. The sequences are aligned, and the base tree was constructed with $>1000$ nt sequences by the neighbor-joining method. Partial sequences $(<1000 \mathrm{nt}$, highlighted with dotted branches) were inserted into the tree using the parsimony insertion tool of the ARB program. 16S rRNA gene sequences of the domain Archaea were used to root the tree (not shown in the tree). Filled circles indicate bootstrap probabilities (based on 1000 replicates) above 95\%. Nodes without symbols were not highly resolved $(<95 \%)$ as specific groups in the analysis. The bar represents $10 \mathrm{nt}$ substitutions per $100 \mathrm{nt}$. The accession number of each reference sequence is shown in parentheses.

tide probes specific to three different regions of the YM-1 sequence (3KSB129, 3KSB652 and 3KSB1128, Table 3). In situ hybridization with the three probes specifically detected thick filaments in the bulking sludge, suggesting that the YM-1 clone was derived from the predominant filamentous organisms. We also designed a phylum-level probe (3KSB1238,
Table 3) targeting all of the known members of the KSB3 phylum, also resulting in the successful detection of the filamentous cells specifically (Figure 1c). From the FISH experiments, the cotton-like materials were found to comprise mostly 3KSB1238 probe-positive filaments (approximately $>90 \%$ of cell area under a microscope), 
Table 3 Fluorescently labeled oligonucleotide probes used in this study

\begin{tabular}{|c|c|c|c|c|c|c|}
\hline Probe name & Target group & Probe sequence $\left(5^{\prime}\right.$ to $\left.3^{\prime}\right)$ & $\begin{array}{l}\text { Probe length } \\
\quad \text { (mer) }\end{array}$ & $\begin{array}{l}\text { Target site (E. } \\
\text { coli position) }\end{array}$ & $\begin{array}{c}\text { Formamide } \\
(\%)\end{array}$ & Reference \\
\hline EUB338 & Domain Bacteria & GCTGCCTCCCGTAGGAGT & 18 & $338-355$ & 10 & $\begin{array}{l}\text { Amann et al. } \\
(1990)\end{array}$ \\
\hline EUB338-II & Domain Bacteria & GCAGCCACCCGTAGGTGT & 18 & $338-355$ & 10 & $\begin{array}{l}\text { Daims et al. } \\
\text { (1999) }\end{array}$ \\
\hline EUB338-III & Domain Bacteria & GCTGCCACCCGTAGGTGT & 18 & $338-355$ & 10 & $\begin{array}{l}\text { Daims et al. } \\
\text { (1999) }\end{array}$ \\
\hline ARC915 & Domain Archaea & GTGCTCCCCCGCCAATTCCT & 20 & 915-935 & 35 & $\begin{array}{l}\text { Stahl et al. } \\
(1988)\end{array}$ \\
\hline GNSB941 & Phylum Chloroflexi & AAACCACACGCTCCGCT & 17 & $941-958$ & 20 & $\begin{array}{l}\text { Gich et al. } \\
\text { (2001) }\end{array}$ \\
\hline GNSB941* & $\begin{array}{l}\text { Masking probe for } \\
\text { GNSB941 }\end{array}$ & AAACCACAAGCTCCGCT & 17 & $941-958$ & 20 & $\begin{array}{l}\text { Yamada } \\
\text { et al. (2005) }\end{array}$ \\
\hline 3KSB129 & Clone YM-1 & CCCATCCCGTGGTCGGTT & 18 & $129-136$ & 30 & This study \\
\hline 3KSB652 & Clone YM-1 & CATCCССТCTGCСACTCT & 18 & $652-674$ & 30 & This study \\
\hline 3KSB1128 & Clone YM-1 & CСССAGCСТCACCTGCT & 18 & $1128-1145$ & 30 & This study \\
\hline $3 \mathrm{KSB} 1238^{\mathrm{a}}$ & Phylum KSB3 & CCGCTGTCCTCCССАTT & 17 & $1238-1255$ & 25 & This study \\
\hline
\end{tabular}

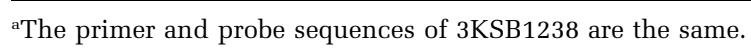

suggesting a significant outbreak of KSB3-type organisms in the bulking sludge. Several unsuccessful attempts were made to isolate the KSB3 filaments from bulking sludge that resulted in enrichment of non-target cells in serially diluted cultures under various aerobic and anaerobic growth conditions.

\section{Spatial distribution of the bulking agent in healthy} sludge granules

We then attempted to determine the distribution of the filamentous organisms in sludge granules that settled well (those before the bulking) with SEM and FISH observations. SEM observation of sectioned granules obtained from the same UASB reactor (CMG reactor) showing no bulking phenomena revealed that unidentified filamentous organisms morphologically similar to the KSB3 filamentous cells were abundant on granule surfaces (Figure 1e). All of the CMG reactor sludge granules observed possessed the same type of filamentous layer on the surface of granules. FISH of sectioned granules using KSB3-specific probes (Table 3) confirmed the identity of the filaments as members of the KSB3 phylum (Figure 1f). All of the 3KSB1238 probereactive cells appeared to be filamentous and all were found only in the outer surface layer of the granules (Figure 1f). Simultaneous detection of cells using EUB338* and 3KSB1238 suggested that the outermost layer of the UASB granules is almost exclusively comprised of KSB3 filaments (data not shown).

\section{Detection and diversity of KSB3 bacteria in various anaerobic sludges}

To reveal the ecological habitats and diversity of the KSB3 candidate phylum, we surveyed ten different types of anaerobic sludges (Table 1) using KSB3 phylum-specific PCR primers (the $27 \mathrm{f}$ and
3KSB1238r primers in Table 3). Following optimization of PCR conditions with the YM-1 clone, amplicons of the expected size ( $1200 \mathrm{nt})$ were obtained from only two types of mesophilic UASB sludge granules; sludge granules fed with wastewater discharged from a beer factory (BMG) and a sugar-processing industry (CMG: original sludge granules before bulking) (Table 1).

For the two samples, the PCR products were cloned, and ten clones were analyzed for each clone library. Comparative analyses of the clone sequences obtained indicated that all were members of the phylum KSB3 closely related ( $>98 \%$ sequence identity) to clone YM-1 (Figure 2) suggesting a possible specialization of this KSB3 phylotype in anaerobic sludges.

\section{Discussion}

In this study, we found a new type of anaerobic filamentous bulking in a full-scale mesophilic UASB process, which were associated with the outbreak of uncultivated microbes belonging to candidate bacterial phylum KSB3. This lineage was proposed on the basis of a single partial sequence (Tanner et al., 2000) and has recently been independently named GN6 by Ley et al. (Ley et al., 2006). We will use KSB3 due to its priority in the literature. The KSB3 filament may be the second bulking agent characterized to date in anaerobic sludge after Anaerolinea thermophila found in thermophilic UASB sludge bulking phenomena (Sekiguchi et al., 2001, 2003). More importantly, the organism is the only identified filamentous microbe that possibly triggers the filamentous bulking of mesophilic anaerobic sludges.

Although we could not directly determine the physiology of the filamentous organisms through axenic cultivation, rRNA-based observations in this 
study suggest part of the ecophysiology (e.g. substrate utilization) of the KSB3 filaments in UASB sludge granules. It has often been observed that UASB sludge granules used to treat carbohydratecontaining wastewater have a layered structure, in which the inner layer consists mostly of aceticlastic methanogens (such as those of the genus Methanosaeta), and the outer layer comprises a diverse array of fermentative bacteria (Harmsen et al., 1996; Sekiguchi et al., 1999; Liu et al., 2002; Yamada et al., 2005). UASB sludge granules in the bulking reactor examined in this study also showed a similar layered structure (Yamada et al., 2005). This distinctive architecture is considered to be a result of substrate profiles within sludge granules (Guiot et al., 1992). Anaerobes in the outer granule layer are thought to ferment organic compounds (such as carbohydrates) present in the wastewater, producing intermediate substances such as fatty acids, alcohols, and hydrogen that are delivered to the interior layers of the granule. Other organisms, such as proton-reducing syntrophic bacteria and methanogenic archaea, present in the middle and inner granule layers decompose such intermediates, finally forming methane in sludge. Organisms present in the outermost granule layers are generally considered to be heterotrophs decomposing primary substrates in the methanogenic degradation of organic pollutants in wastewater.

We predict that the studied KSB3 filaments are heterotrophs that ferment sugars since (i) KSB3 cells were found only in the outer most layer of the healthy CMG sludge granules (Figure 1), and (ii) the CMG sludge was fed with a sugar-processing wastewater (such as those for isomerized sugars).

Carbohydrate-utilizing filaments are often observed at the surface of granules treating carbohydrate-containing wastewater (Uemura et al., 1993; Sekiguchi et al., 2001; Yamada et al., 2005) supporting our prediction. For example, filamentous cells belonging to subphylum 1 (the class Anaerolineae (Yamada et al., 2006)) of the phylum Chloroflexi entirely covered the outer most layer of thermophilic (Sekiguchi et al., 1999; Yamada et al., 2005) and mesophilic UASB sludge granules (Yamada et al., 2005) forming a web-like structure. Four filamentous strains of Anaerolineae were recently isolated from mesophilic and thermophilic UASB sludge granules and characterized in detail (Sekiguchi et al., 2003; Yamada et al., 2005, 2006) confirming their ability to ferment carbohydrates (Sekiguchi et al., 2003; Yamada et al., 2005). Among them, $A$. thermophila was noted as the causative agent for thermophilic sludge bulking (Sekiguchi et al., 2001).

Factors that actually triggered the filamentous bulking remain unknown. In previous reports, however, it was observed that filamentous microbes overgrew by sudden increases in the carbohydrate concentration in wastewater, and that fluffy sludge granules were formed (Wu et al., 1993; Alphenaar,
1994; Yoda and Nishimura, 1997; Angenent and Sung, 2001). Outbreaks of filamentous organisms were also found in anaerobic sludge treating carbohydrate-containing wastewater (Endo and Tohya, 1988). Recently, a similar bulking behavior caused by the outbreak of $A$. thermophila cells was noted in thermophilic UASB sludge granules following an increase in the carbohydrate concentration (Sekiguchi et al., 2001). Given the parallels between $A$. thermophila and KSB3 filament ecophysiology, increases in carbohydrate loading may also trigger KSB3 bulking, although we did not monitor the changes in the carbohydrate concentration in the wastewater during the bulking episode.

Phylogenetic analyses in this study revealed that candidate phylum KSB3 currently comprises ten environmental partial to near full-length $16 \mathrm{~S}$ rRNA gene clones, of which seven were obtained from anaerobic sludge and the remainder from saline natural environments (Figure 2). The present study showed that a single KSB3 phylotype (based on a $97 \%$ sequence identity threshold) was found in 2 out of ten anaerobic sludges. Additionally, we attempted to amplify KSB3 phylotypes in environmental samples such as activated sludges, rice paddy soils, land soils, and sediments of river, lake and coast using the KSB3-specific primer set, resulting in no PCR amplification from all of the samples examined (unpublished data), suggesting a narrow range of habitats for KSB3 organisms, or that our primers may not target all members of the KSB3 phylum. 16S rRNA gene sequence divergence of the KSB3 phylum (15\% sequence difference) is relatively low when compared to other known phyla of the domain Bacteria (Dojka et al., 2000). The observed habitat range and limited sequence divergence of members of KSB3 may reflect their specific growth traits, or an incomplete sampling of the phylum.

In conclusion, we found that filamentous cells, affiliated with candidate bacterial phylum KSB3 (GN6), were associated with fluffy UASB sludge (bulking sludge) formation. We further revealed that the KSB3 filaments were abundant in the outer most layer of healthy sludge granules (those before bulking), forming a web-like structure on them, implying key roles in stabilization of granule structure and primary substrate fermentation in wastewater, possibly carbohydrates. Members of the KSB3 lineage currently appear to occupy a relatively narrow range of habitats. Further studies on KSB3 bacteria will contribute to a better understanding of the mechanisms underlying bulking formation in anaerobic sludges and the overall ecophysiology of this group.

\section{Acknowledgements}

This study was carried out as a part of the project, which was entrusted to the New Energy and Industrial Technology Development Organization (NEDO), Tokyo, 
Japan. This study was also supported financially by research grant 1552481 from the Grants-in-Aid for JSPS Fellows and by several research grants from the Ministry of Education, Culture, Sports, Science and Technology, Japan. This work was also performed, in part, under the auspices of the DOE's Office of Science, Biological and Environmental Research Program; the University of California, Lawrence Livermore National Laboratory, under contract no. W-7405-Eng-48; Lawrence Berkeley National Laboratory under contract no. DE-AC0376SF00098; and Los Alamos National Laboratory under contract no. W-7405-ENG-36.

\section{References}

Alphenaar PA. (1994). Anaerobic granular sludge: characterization and factors its functioning. $\mathrm{PhD}$ dissertation, Wageningen Agricultural University, Wageningen, The Netherlands.

Amann RI, Binder BJ, Olson RJ, Chisholm SW, Devereux R, Stahl DA. (1990). Combination of $16 \mathrm{~S}$ rRNAtargeted oligonucleotide probes with flow cytometry for analyzing mixed microbial populations. Appl Environ Microbiol 56: 1919-1925.

Angenent LT, Sung S. (2001). Development of anaerobic migrating blanket reactor (AMBR), a novel anaerobic treatment system. Wat Res 35: 1739-1747.

Björnsson L, Hugenholtz P, Tyson GW, Blackall LL. (2002). Filamentous Chloroflexi (green non-sulfur bacteria) are abundant in wastewater treatment processes with biological nutrient removal. Microbiology 148: 2309-2318.

Clesceri LS, Greenberg AE, Eaton AD. (1998). Standard Methods for the Examination of Water and Wastewater, 20th edn. APHA AWWA WEF: USA.

Daims H, Brühl A, Amann R, Schleifer K, Wagner M. (1999). The domain-specific probe EUB338 is insufficient for the detection of all Bacteria: development and evaluation of a more comprehensive probe set. System Appl Microbiol 22: 434-444.

Dojka MA, Harris JK, Pace NR. (2000). Expanding the known diversity and environmental distribution of an uncultured phylogenetic division of bacteria. Appl Environ Microbiol 66: 1617-1621.

Donlon B, Razo-Flores E, Luijten M, Swarts H, Lettinga G, Field J. (1997). Detoxification and partial mineralization of the azo dye mordant orange 1 in a continuous upflow anaerobic sludge-blanket reactor. Appl Environ Biotechnol 47: 83-90.

Endo G, Tohya Y. (1988). Ecological study on anaerobic sludge bulking caused by filamentous bacterial growth in anaerobic contact process. Wat Sci Tech 20: 205-211.

Felsenstein J. (1985). Confidence limits on phylogenies: an approach using the bootstrap. Evolution 39: 783-791.

Gich F, Garcia-Gil J, Overmann J. (2001). Previously unknown and phylogenetically diverse members of the green nonsulfur bacteria are indigeneous to freshwater lakes. Arch Microbiol 177: 1-10.

Guiot SR, Pauss A, Costerton JW. (1992). A structured model of the anaerobic granule consortium. Wat Sci Tech 25: 1-10.

Harmsen HJM, Kengen HMP, Akkermans ADL, Stams AJM, de Vos WM. (1996). Detection and localization of syntrophic propionate-oxidizing bacteria in granular sludge by in situ hybridization using 16S rRNA-based oligonucleotide probes. Appl Environ Microbiol 62: 1656-1663.

Hugenholtz P, Huber T. (2003). Chimeric 16S rDNA sequences of diverse origin are accumulating in the public databases. Int J Syst Evol Microbiol 53: 289-293.

Imachi H, Sekiguchi Y, Kamagata Y, Hanada S, Ohashi A, Harada H. (2002). Pelotomaculum thermopropionica gen. nov., sp. nov., an anaerobic, thermophilic, syntrophic propionate-oxidizing bacterium. Int J Syst Evol Microbiol 52: 1729-1735.

Jobb G. (2005). TREEFINDER version of June 2005. Munich, Germany. Distributed by the author at www. treefinder.de.

Kleerebenzem R, Macarie H. (2003). Treating industrial wastewater: Anaerobic digestion comes of age. Chem Eng April, 2003: 56-65.

Kosaric N, Blaszczyk R, Orphan L, Valladares J. (1990). The characteristics of granules from upflow anaerobic sludge blanket reactors. Water Res 24: 1473-1477.

Lepistš R, Rintala J. (1999). Extreme thermophilic $\left(70^{\circ} \mathrm{C}\right)$, VFA-fed UASB reactor: performance, temperature response, load potential and comparison with 35 and $55{ }^{\circ} \mathrm{C}$ UASB reactors. Water Res 33: 3162-3170.

Lettinga G. (1995). Anaerobic digestion and wastewater treatment systems. Antonie van Leeuwenhoek 67: 3-28.

Lettinga G, Rebac S, Zeeman G. (2001). Challenge of psychrophilic anaerobic wastewater treatment. Trends in Biotechnol 19: 363-370.

Ley RE, Harris JK, Wilcox J, Spear JR, Miller SR, Bebout $\mathrm{BM}$ et al. (2006). Unexpected diversity and complexity of the Gurrero Negro Hypersaline Microbial Mat. Appl Environ Microbiol 72: 3685-3695.

Liu W-T, Chan O-C, Fang HHP. (2002). Characterization of microbial community in granular sludge treating brewery wastewater. Water Res 36: 1767-1775.

Lowry OH, Rosbrough NJ, Farr AL, Randall RJ. (1951). Protein measurement with folin phenol reagent. J Biol Chem 193: 265.

Ludwig W, Strunk O, Westram R, Richter L, Meier H, Yadhukumar et al. (2004). ARB: a software environment for sequence data. Nucleic Acids Res 32: 1363-1371.

Miller DN, Bryant JE, Madsen EL, Ghiorse WC. (1999). Evaluation and optimization of DNA extraction and purification procedures for soil and sediment samples. Appl Environ Microbiol 65: 4715-4724.

Rebac S, van Lier JB, Lens P, Stams AJM, Dekkers F, Swinkels KTM et al. (1999). Psychrophilic anaerobic treatment of low strength wastewaters. Water Sci Tech 39: 203-210.

Ronquist F, Huelsenbeck JP. (2003). MrBayes 3: Bayesian phylogenetic inference under mixed models. Bioinformatics 19: 1572-1574.

Saitou N, Nei M. (1987). The neighbor-joining method: A new method for reconstructing phylogenetic trees. Mol Biol Evol 4: 406-425.

Sekiguchi Y, Kamagata Y. (2004). Strict and facultative anaerobes: medical and environmental aspects. In: Nakano MM, Zuber P (eds). Microbial Community Structure and Functions in Methane Fermentation Technology for Wastewater Treatment. Horizon Bioscience: UK, pp 361-384. 
Sekiguchi Y, Kamagata Y, Nakamura K, Ohashi A, Harada H. (1999). Fluorescence in situ hybridization using $16 S$ rRNA-targeted oligonucleotides reveals localization of methanogens and selected uncultured bacteria in mesophilic and thermophilic sludge granules. Appl Environ Microbiol 65: 1280-1288.

Sekiguchi Y, Kamagata Y, Syutsubo K, Ohashi A, Harada H, Nakamura K. (1998). Phylogenetic diversity of mesophilic and thermophilic granular sludges determined by $16 \mathrm{~S}$ rRNA gene analysis. Microbiology 144: 2655-2665.

Sekiguchi Y, Takahashi H, Kamagata Y, Ohashi A, Harada H. (2001). In situ detection, isolation, physiological properties of a thin filamentous microorganism abundant in methanogenic granular sludges: a novel isolate affiliated with a clone cluster, the green non-sulfur bacteria, subdivision I. Appl Environ Microbiol 67: 5740-5749.

Sekiguchi Y, Yamada T, Hanada S, Ohashi A, Harada H, Kamagata Y. (2003). Anaerolinea thermophila gen. nov., sp. nov. and Caldilinea aerophila gen. nov., sp. nov., novel filamentous thermophiles that represent a previously uncultured lineage of the domain Bacteria at the subphylum level. Int J Syst Evol Microbiol 53: 1843-1851.

Stahl DA, Flesher B, Mansfield HR, Montgomery L. (1988). Use of phylogenetically based hybridization probes for studies of ruminal microbial ecology. Appl Environ Microbiol 54: 1079-1084.

Swofford DL. (2002). PAUP*: Phylogenetic analysis using parsimony (* and other methods) version 4. Sinauer Associates: Sunderland, MA.

Tanner MA, Everett CL, Coleman WJ, Yang MM, Youvan DC. (2000). Complex microbial communities inhabiting sulfide-rich black mud from marine coastal environments. Biotechnology 8: 1-16.

Uemura S, Harada H. (1993). Microbial characteristics of methanogenic sludge consortia developed in thermophilic UASB reactors. Appl Microbiol Biotechnol 39: 654-660.

Uemura S, Harada H. (2000). Treatment of sewage by a UASB reactor under moderate to low temperature conditions. Biores Tech 72: 275-282.

Vallero MVG, Camarero E, Lettinga G, Lens PNL. (2004). Thermophilic $\left(55-65^{\circ} \mathrm{C}\right)$ and extreme thermophilic $\left(70-80^{\circ} \mathrm{C}\right)$ sulfate reduction in methanol and formatefed UASB reactors. Biotechnol Prog 20: 1382-1392.

van der Zee FP, Lettinga G, Field JA. (2001). Azo dye decolourisation by anaerobic granular sludge. Chemosphere 44: 1169-1176.

Weisburg WG, Barns SM, Pelletier DA, Lane DJ. (1991). 16S ribosomal DNA amplification for phylogenetic study. J Bacteriol 173: 697-703.

Wu W-M, Thiele JH, Jain MK, Pankratz HS, Hickey RF, Zeikus JG. (1993). Comparison of rod- versus filamenttype methanogenic granules: microbial population and reactor performance. Appl Environ Biotechnol 39: 795-803.

Yamada T, Sekiguchi Y, Hanada S, Imachi H, Ohashi A, Harada $\mathrm{H}$ et al. (2006). Anaerolinea thermolimosa sp. nov., Levilinea saccharolytica gen. nov., sp. nov. and Leptolinea tardivitalis gen. nov., sp. nov., novel filamentous anaerobes, and description of the new classes Anaerolineae classis nov. and Caldilineae classis nov. in the bacterial phylum Chloroflexi. Int J Syst Evol Bacteriol 56: 1331-1340.

Yamada T, Sekiguchi Y, Imachi H, Kamagata Y, Ohashi A, Harada H. (2005). Diversity, localization and physiological properties of filamentous microbes belonging to Chloroflexi subphylum I in mesophilic and thermophilic methanogenic sludge granules. Appl Environ Microbiol 71: 7493-7503.

Yamaguchi T, Yamazaki S, Uemura S, Tseng I-C, Ohashi A, Harada H. (2001). Microbial-ecological significant of sulfide precipitation within anaerobic granular sludge revealed by micro-electrodes study. Water Res 35: 3411-3417.

Yoda M, Kitagawa M, Miyaji Y. (1989). Granular sludge formation in the anaerobic expanded microcarrier bed process. Wat Sci Tech 21: 109-120.

Yoda M, Nishimura S. (1997). Controlling granular sludge floating in UASB reactors. Water Sci Tech 36: 165-173.

Zhang H, Sekiguchi Y, Hanada S, Hugenholtz P, Kim H, Kamagata Y et al. (2003). Gemmatimonas aurantiaca gen. nov., sp. nov., a Gram-negative, aerobic, polyphosphate-accumulating micro-organism, the first cultured representative of the new bacterial phylum Gemmatimonadetes phyl nov. Int J Syst Evol Microbiol 53: 1155-1163. 